\title{
Genetic Variability and Changes of Elemental Concentrations in Cells of Tetrix tenuicornis (Orthoptera: Tetrigidae) from Polluted and Unpolluted Areas
}

\author{
Beata GRZYWACZ, Elżbieta WARChAŁOWSKA-ŚLIWA, Zuzanna BANACH and Elżbieta PYZA
}

Accepted October 5, 2011

\begin{abstract}
GrZywaCZ B., WARChA£OWSKA-ŚLIWA E, BANACH Z., PYZA E. 2012. Genetic variability and changes of elemental concentrations in cells of Tetrix tenuicornis (Orthoptera: Tetrigidae) from polluted and unpolluted areas. Folia biologica (Kraków) 60: 17-25.

Genetic variability between populations of the orthopteran insect Tetrix tenuicornis, collected from six locations in Poland, was assayed by using the random amplified polymorphic DNA-polymerase chain reaction (RAPD-PCR) method. The results show that insects in a population from metal polluted areas in Bolesław have reduced genetic variability in contrast to five other populations located in unpolluted areas. The insects from polluted sites also showed significant changes in elemental concentrations in nerve and muscle cells, measured by X-ray spectroscopy, when compared to insects of the same species collected from unpolluted sites.

Key words: DNA variability; RAPD-PCR; ionic concentrations in cells; insects; Orthoptera Tetrix.

Beata GRZYWACZ, Elżbieta WARCHAEOWSKA-ŚLIWA, Department of Experimental Zoology, Institute of Systematics and Evolution of Animals, Polish Academy of Sciences, Stawkow ska 17. 31-016 Kraków, Poland.

E-mail: grzywacz@isez.pan.krakow.pl

Zuzanna BANACH, Elżbieta PYZA, Department of Cytology and Histology, Institute of Zoology, Jagiellonian University, Ingardena 6, 30-060 Kraków, Poland.
\end{abstract}

Environmental effects have been detected by determining how different environmental conditions influence mutation rates, the stability of an organism's development, and how genes interact with the environment to produce phenotypes (HoFFMAN \& PARSONS 1997). This is especially important for species which invade heavily polluted environments, such as heavy metal processing industrial areas, and persist in stable populations under these conditions. Such organisms accumulate large amounts of heavy metals in tissues but are able to develop efficient mechanisms of detoxification and other adaptations for life in a polluted environment. It is known that heavy metals are genotoxic, neurotoxic and affect many physiological and cellular processes in all organisms which have been studied so far (ROSS et al. 2002; BONACKER et al. 2005; FLOREA \& BÜSSELBERG 2006). They affect development, fertility and survival depending on their concentrations in the environment, interactions and influences of other environmental factors (BOROWSKA et al. 2004).
The present study is a continuation of our research on heavy metal genotoxicity and cytotoxicity in $T$. tenuicornis from populations living in contaminated and uncontaminated sites. Individuals collected from polluted areas accumulates heavy metals that leads to whole body concentrations of zinc $(\mathrm{Zn})$, lead $(\mathrm{Pb})$, copper $(\mathrm{Cu})$, and cadmium $(\mathrm{Cd})$ that are $4.03,4.32,1.5$ and 41.73 times higher, respectively, than in insects of the same species from unpolluted areas. A cytogenetic analysis of this species, intoxicated by heavy metals, also showed several anomalies in chromosome number and their morphology during mitosis (WARCHAŁOWSKA-ŚLIWA et al. 2005).

In the present study, random amplified DNA polymorphism (RAPD) revealed by the polymerase chain reaction method (RAPD-PCR) have been applied to investigate effects of heavy metals at the population level by studying the phenetic structure of $T$. tenuicornis populations from polluted and unpolluted sites. The RAPD method has been used by other authors to generate molecular markers and analyze genetic and phenetic vari- 
abilities in different organisms, including humans, fungi and plants (WILLIAMS et al. 1991; LARK et al. 1992; KOLLER et al. 1993; STILES et al. 1993) and insects (BLACK et al. 1992; ZHOU et al. 2000; SHARMA et al. 2003; KIM \& SAPPINGTON 2004; SESARINI \& REMIS 2008). It has already been applied in ecotoxicology (WOLF et al. 2004) to diagnose the genotoxicity of copper (ATIENZAR et al. 2001), lead and other metals (Ross et al. 2002), benzo[a]pirene (ATIENZAR et al. 1999, 2002a, 2002b), and UV or X rays (ATIENZAR et al. 2000; JONES \& KORTENKAMP 2000). This technique is useful for the preliminary screening of populations for genotoxic effects and for determining the phenetic/genetic diversity in natural populations exposed to pollutants (WOLF et al. 2004). Moreover, the RAPD-PCR method needs very small quantities of DNA, explores many loci, and neither cloning nor sequencing is necessary in comparison with other molecular techniques used for genomic characterization (FRAGA et al. 2005).

Since populations of $T$. tenuicornis are stable in contaminated sites, the insects seem to tolerate heavy metal toxicity, however, the physiological changes at the cellular level in these insects are unknown. So, in addition to the study at the population level, we examined heavy metal intoxication at the cellular level by comparing concentrations of major elements in cells of the nervous and muscle systems. Any changes in the concentration of sodium $(\mathrm{Na})$, potassium $(\mathrm{K})$, chloride $(\mathrm{Cl})$, magnesium $(\mathrm{Mg})$, sulphur $(\mathrm{S})$ and phosphorus $(\mathrm{P})$ disrupt the physiology of these cells. In an earlier study we found that changes in concentrations of elements in cells of different tissues are correlated with heavy metal accumulation in these tissues (TYLKO et al. 2005). To evaluate the effects of heavy metals on neurons and muscles, we carried out an Xray microanalysis of selected elements important for cell metabolism in insects collected from populations from polluted and unpolluted areas.

Heavy metals are easily absorbed through the body surface or via the digestive tract and accumulated in specific tissues where they are immobilized, or are present in blood affecting different cell types. In a previous study we found that heavy metals influence the elemental composition of cells, even those protected by the blood-brain barrier and which are not the main targets for heavy metals, such as neurons (TYLKO et al. 2005). Cells affected by heavy metals include immunocompetent cells, decreasing the functioning of the immune system and as a consequence the survival of the animal. In the housefly, a model organism for metal toxicity, exposure to heavy metals during development under laboratory conditions significantly decreases the number and alters the function of haemocytes, i.e. insect blood cells (BOROWSKA et al. 2004). Elemental changes in other cells, such as neurons and muscle cells, lead to serious dysfunctions of the nervous system and muscles (TYLKO et al. 2005) affecting animal behaviour, survival and longevity.

There are organisms however, that are able to develop a tolerance to heavy metal toxicity. This has been observed mostly in plants (CHIANG et al. 2006) and fungi (ZAFAR et al. 2006), but also reported in animals (BARSYTE et al. 2001). Such species are especially informative in relation to the adaptive processes enabling survival in environments altered as a result of industrialization.

The aim of our study was to carry out a diagnostic analysis of RAPD band similarity of $T$. tenicornis populations from heavy metal polluted and unpolluted sites as well as to examine the concentration of $\mathrm{Na}, \mathrm{K}, \mathrm{Cl}, \mathrm{Mg}, \mathrm{S}$ and $\mathrm{P}$ in neurons and muscles of insects originating from these populations in order to investigate their physiological condition.

\section{Material and Methods}

\section{RAPD analysis of genetic polymorphisms}

A total of 90 specimens of 6 populations of T. tenuicornis were analysed. Adults, both male and female, of $T$. tenuicornis were collected from a population in a polluted area located near Bolesław $\left(50^{\circ} 17^{\prime} \mathrm{N}\right.$ $19^{\circ} 28^{\prime} \mathrm{E}$ ) as well as from five populations from unpolluted areas in Wełecz near Busko $\left(50^{\circ} 28^{\prime} \mathrm{N} 20^{\circ} 41^{\prime} \mathrm{E}\right)$, Jasło $\left(49^{\circ} 44^{\prime} \mathrm{N}\right.$ 42.20"E), Grabowiec $\left(50^{\circ} 28^{\prime} \mathrm{N}\right.$ $\left.20^{\circ} 34^{\prime} \mathrm{E}\right)$, Łuczyce $\left(50^{\circ} 09^{\prime} \mathrm{N} 20^{\circ} 04^{\prime} \mathrm{E}\right)$, and Żurawica $\left(50^{\circ} 33^{\prime} \mathrm{N} 21^{\circ} 33^{\prime} \mathrm{E}\right)$ between $2002-2005$ in Poland. At least 15 individuals per population were examined. The heavily contaminated areas near Bolesław are located $2.5 \mathrm{~km}$ from two zinclead ore smelters in Olkusz, in southern Poland. Heavy metal concentrations $(\mathrm{Zn}, \mathrm{Cd}, \mathrm{Cu}$ and $\mathrm{Pb})$ in the bodies of insects from Bolesław and Wełecz collected in 2002 have been examined in an earlier study (WARCHAŁOWSKA-ŚLIWA et al. 2005).

Genomic DNA was extracted from one leg of each insect using a QIAamp ${ }^{\mathrm{TM}}$ DNA Dneasy Tissue Kit (Qiagen ${ }^{\text {TM }}$ Germany) according to the manufacturer's protocol. The RAPD assay was performed in $20 \mu \mathrm{l}$ volumes containing: $2 \mu \mathrm{l}$ of DNA template, $2 \mu 110 \times$ PCR buffer (Qiagen), 0.8 $\mu \mathrm{l}$ of $\mathrm{MgCl}_{2}, 0.4 \mu \mathrm{l}$ of deoxynucleotide triphosphates (dNTPs), $0.2 \mu$ l of Taq DNA polymerase (Qiagen). Amplification was performed using a MJ research Minicycler. The PCR reaction started with an initial denaturation for $4 \mathrm{~min}$ at $94^{\circ} \mathrm{C}$, followed by 40 cycles for: $1 \mathrm{~min}$ at $94^{\circ} \mathrm{C}, 1 \mathrm{~min}$ at $35^{\circ} \mathrm{C}$ and $2.5 \mathrm{~min}$ at $72^{\circ} \mathrm{C}$. After amplification, the solutions were stored at $4^{\circ} \mathrm{C}$ until electrophoresis 
and visualization. RAPD reactions on the DNA of each individual was repeated three times. As a result of this procedure identical band patterns were obtained indicating the reliability of the method. RAPD PCR products were mixed with a loading buffer and separated by electrophoresis in $2 \%$ agarose gel with ethidium bromide in TBE (Trisborate-EDTA) at $50 \mathrm{~V}$ for $3 \mathrm{~h}$. Specific bands were detected using fluorescent or silver tags and UV transillumination.

Twenty 10-nucleotide primers, used in other studies of orthopteran species genomes (JIANG \& LU 2003; LI \& ZHENG 2003; SESARINI \& REMIS 2008), were initially screened using ten samples of DNA from each population of T. tenuicornis. Primers were synthesized in the Institute of Biochemistry and Biophysics of the Polish Academy of Sciences in Poland. Their sequences are given in Table 1.

The Bio1D++ software (Vilbert Lourmat, France) was used to calculate intra- and interpopulation relationships on the basis of the similarity of DNA band patterns obtained with the RAPD methods, according to NEI and LI'S (1979) and Jackard's (SNEATH 1957; SOKAL \& MICHENDER 1958) similarity coefficients, i.e. $\mathrm{S}=2 \mathrm{~N}_{\mathrm{AB}} /$

Table 1

Primers used in amplification of the DNA of $T$. tenuicornis

\begin{tabular}{|c|c|}
\hline Name & Sequence (5' to 3') \\
\hline A01 & CCCAAGGTCC \\
\hline A04 & CTTCACCCGA \\
\hline A05 & CACCAGGTGA \\
\hline A09 & CTAATGCCGT \\
\hline B07 & AGATCGAGCC \\
\hline B10 & CAGGCACTAG \\
\hline S4 & GGACTGGAGT \\
\hline S8 & GTCCACACGG \\
\hline S13 & TTCCCCCGCT \\
\hline S15 & GGAGGGTGTT \\
\hline S18 & CCACAGCAGT \\
\hline S20 & GGACCCTTAC \\
\hline S50 & GGTCTACACC \\
\hline S55 & CATCCGTGCT \\
\hline S61 & TTCGAGCCAG \\
\hline S83 & GAGCCCTCCA \\
\hline S97 & ACGACCGACA \\
\hline S102 & TCGGACGTGA \\
\hline S361 & CATTCGAGCC \\
\hline S379 & CACAGGCGGA \\
\hline
\end{tabular}

$\left(\mathrm{N}_{\mathrm{A}}+\mathrm{N}_{\mathrm{B}}\right)$ where: $\mathrm{N}_{\mathrm{AB}}$ is the number of shared bands in both individuals $A$ and $B ; N_{A}$ and $N_{B}$ are the number of bands in individual $\mathrm{A}$ and $\mathrm{B}$, respectively, and $C_{j}=j / x+y-j$, where: $j$ is the number of shared bands in both individuals $\mathrm{A}$ and $\mathrm{B}$; $\mathrm{x}$ is the number of bands in individual $\mathrm{A}$, and $\mathrm{y}$ is the number of bands in individual B. Dendrograms were constructed on the basis of the similarity values in the matrix using the unweighted pair group match average (UPGMA). The UPGMA algorithm is a phenetic distance method (NEI 1987; PAGE \& HOLMES 1998; GRAUR \& Li 2000) employing a sequential clustering algorithm. The results of DNA electrophoresis were entered into the database as 0 or 1 meaning absence or presence of a band, respectively.

\section{$\mathrm{X}$ - ray microanalysis}

We analysed 40 and 32 muscle samples and 33 and 36 brain samples of $T$. tenuicornis from Wełecz and Bolesław, respectively, according to the methods described by TYLKO et al. (2005). Analyses were carried out to estimate the elemental concentrations of $\mathrm{Na}, \mathrm{K}, \mathrm{Cl}, \mathrm{Mg}, \mathrm{S}$ and $\mathrm{P}$ in the brain cells and muscle fibres of legs.

Insects were sacrificed by freezing at $-30^{\circ} \mathrm{C}$ for $10 \mathrm{~min}$, covered with 2-methylcellulose (Agar Scientific Inc.) and plunged into isopentane cooled to $-140^{\circ} \mathrm{C}$ with liquid nitrogen. Brains and legs were cut into $30 \mathrm{~m}$ sections using a cryostat. Next, the sections were lyophilized in $-30^{\circ} \mathrm{C}$ under a vacuum of $210^{-2}$ Torr for $4 \mathrm{~h}$ at $-30^{\circ} \mathrm{C}$ and left in the vacuum, in room temperature, overnight. After lyophilization they were covered with a $20 \mathrm{~nm}$ carbon layer to prevent a charging effect (JEOL JEE-4C, JVG-N1, Japan) and 24 quantitative Xray microanalyses of each tissue (in pointed mode) were performed by means of EDXMA using a scanning electron microscope (SEM) (JEOL JSM-5410, Japan) equipped with a NORAN 30 $\mathrm{mm}^{2} \mathrm{Si}(\mathrm{Li})$ detector (679A-3SES, Noran Instruments Inc). The following conditions of analyses were used: $100 \mathrm{~s}$ of live time, at $10 \mathrm{keV}$ of accelerating voltage and probe current $0.3 \mathrm{nA}$ measured on pure aluminium. Quantitative analyses were based on calibration curves obtained on gelatin standards containing mineral salts $\left(\mathrm{NaCl}, \mathrm{MgSO}_{4}\right.$, $\mathrm{K}_{2} \mathrm{PO}_{4}$ ) (TYLKO et al. 2004). Spectra were obtained from leg muscle fibres and brain cells, analysed on the basis of the "top-hat" filtering method combined with least-squares fitting (STATHAM 1977), and net counts of collected X-ray quanta were calculated. The detection limits for elements were estimated on the basis of the GOLDSTEIN and YAKOWITZ (1975) equation. For statistical analysis of normality the Kolomogorov-Smirnov test was used followed by an analysis of variance 
(ANOVA) and Tukey's test $(\mathrm{P}<0.05)$. In case of non-normal data distribution, the Mann-Whitney U-test was used.

\section{Results}

\section{RAPD-PCR analysis}

The twenty selected primers were used to examine the level of polymorphism detectable in the six populations of T. tenuicornis. Clear amplification was produced by only 7 primers while 13 primers produced either a smear or no amplification at all. Thus, all insects were examined using seven primers: S4, S8, S18, S20, S83, S97, S397 (see Table 1). They produced the highest number of scorable bands that would be able to differentiate between populations. Fig. 1, as an example, shows the electrophoretic pattern using primer S83. All amplifications were repeated at least twice in order to confirm the reproducible amplification of scored and compiled into a data matrix. The marked changes observed in RAPD profiles (disappearance and/or appearance of bands in comparison with negative control) were evaluated. These primers amplified a total of 0-7 bands in the molecular weight range of approximately
100-1031 bp based on the MassRuler ${ }^{\mathrm{TM}}$ Low Range DNA Ladder, ready-to-use, molecular marker. It was very hard to find bands which were characteristic for individuals in 6 populations. Of all primers tested, primer $\mathrm{S} 83$ yielded clear, sharp, polymorphic band patterns, and hence was used for comparative analysis of $T$. tenuicornis. Of all primers tested, both S83 (Fig. 1) and S4 (Fig. 2) yielded clear, sharp, polymorphic band patterns. The primer S83 was more informative than S4, which uniformly amplified a few bands and of minimum molecular weight of $200 \mathrm{bp}$ in most of the samples in each population.

Clustering analysis the UPGMA algorithm and NEI and LI'S (1979) coefficient produced the following dendrogram (Fig. 3) separating 30 individuals from six populations into two main clusters. The highest values for NEI and LI'S (1979) (NL) similarity coefficient within population was obtained from samples from Bolesław (NL $=100 \%-75 \%$ ), followed by Wełecz (NL $=100 \%-40 \%$ ), Jasło ( $\mathrm{NL}=100 \%-57 \%)$, Grabowiec (NL $=100 \%-86 \%$ ), Euczyce $(\mathrm{NL}=100 \%-71 \%)$ and Żurawica (NL $=$ 100\%-33\%). Interpopulation similarity coefficients calculated for Bolesław and Grabowiec $(\mathrm{NL}=67 \%)$, Bolesław and Łuczyce $(67 \%)$ as well as for Bolesław and Jasło (NL $=62 \%)$, were higher than the value for Welecz and Grabowiec ( $\mathrm{NL}=18 \%$ ), Wełecz-Jasło (NL = 18\%), Wełecz-Łuczyce (20\%).

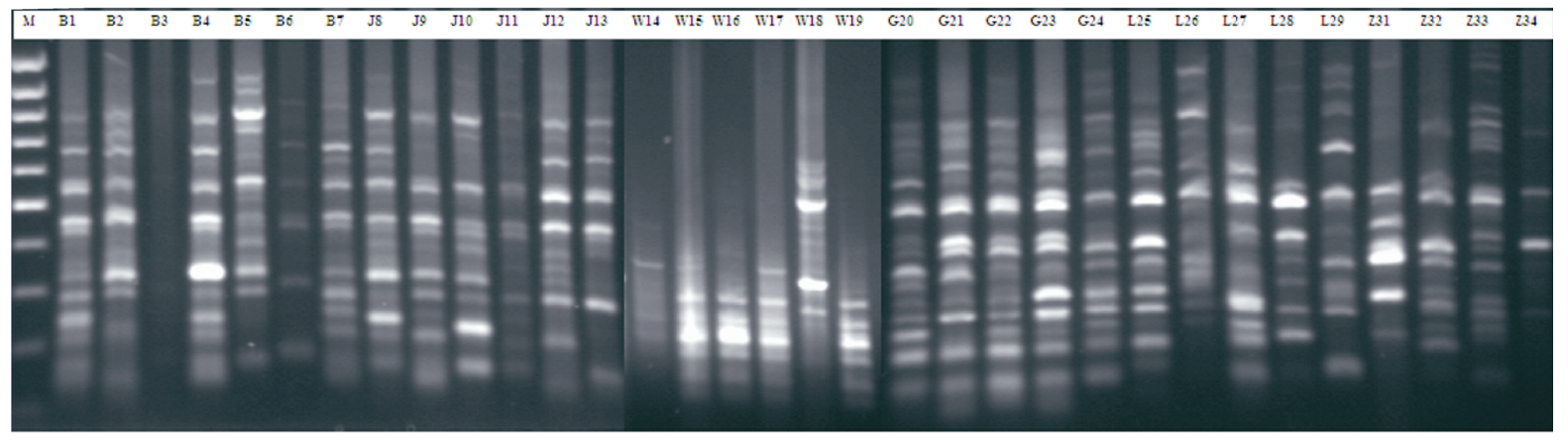

Fig. 1. RAPD band pattern of T. tenuicornis with S83 primer. Lane 1 - molecular weight marker (Fermentas), lanes B1-B7 specimens collected in Bolesław, lanes J8-J13 - Jasło, lanes W14-W19 - Wełecz, lanes G20-G24 - Grabowiec, lanes L25-L29 - Luczyce, lanes Z31-Z34 - Zurawica.

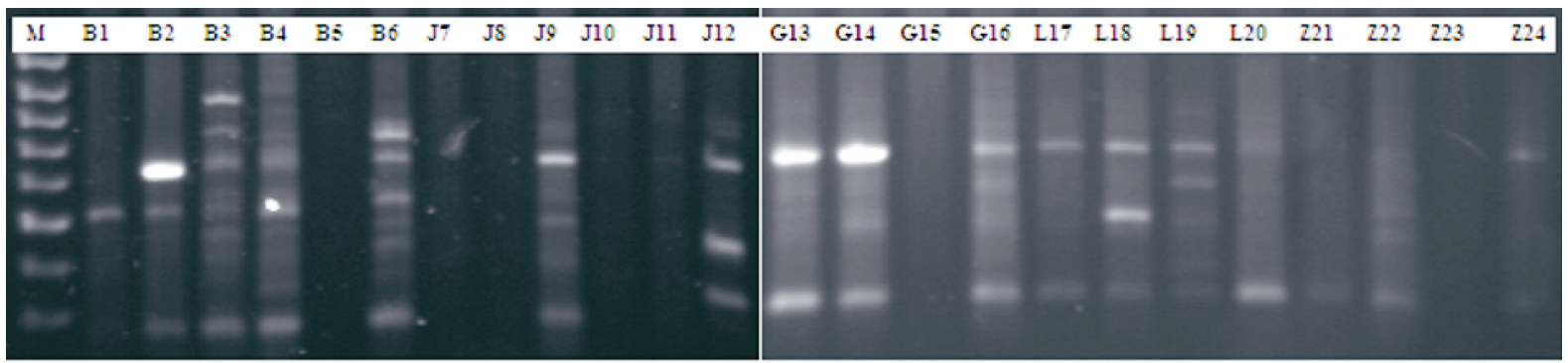

Fig. 2. RAPD band pattern of S4 genomic DNA of T. tenuicornis. Lane 1 - molecular weight marker (Fermentas), lanes B1-B6 specimens collected in Bolesław, lanes J7-J12 - Jasło, lanes G13-G16 - Grabowiec, lanes L17-L20 - Łuczyce, lanes Z21-Z24 - Zurawica. 


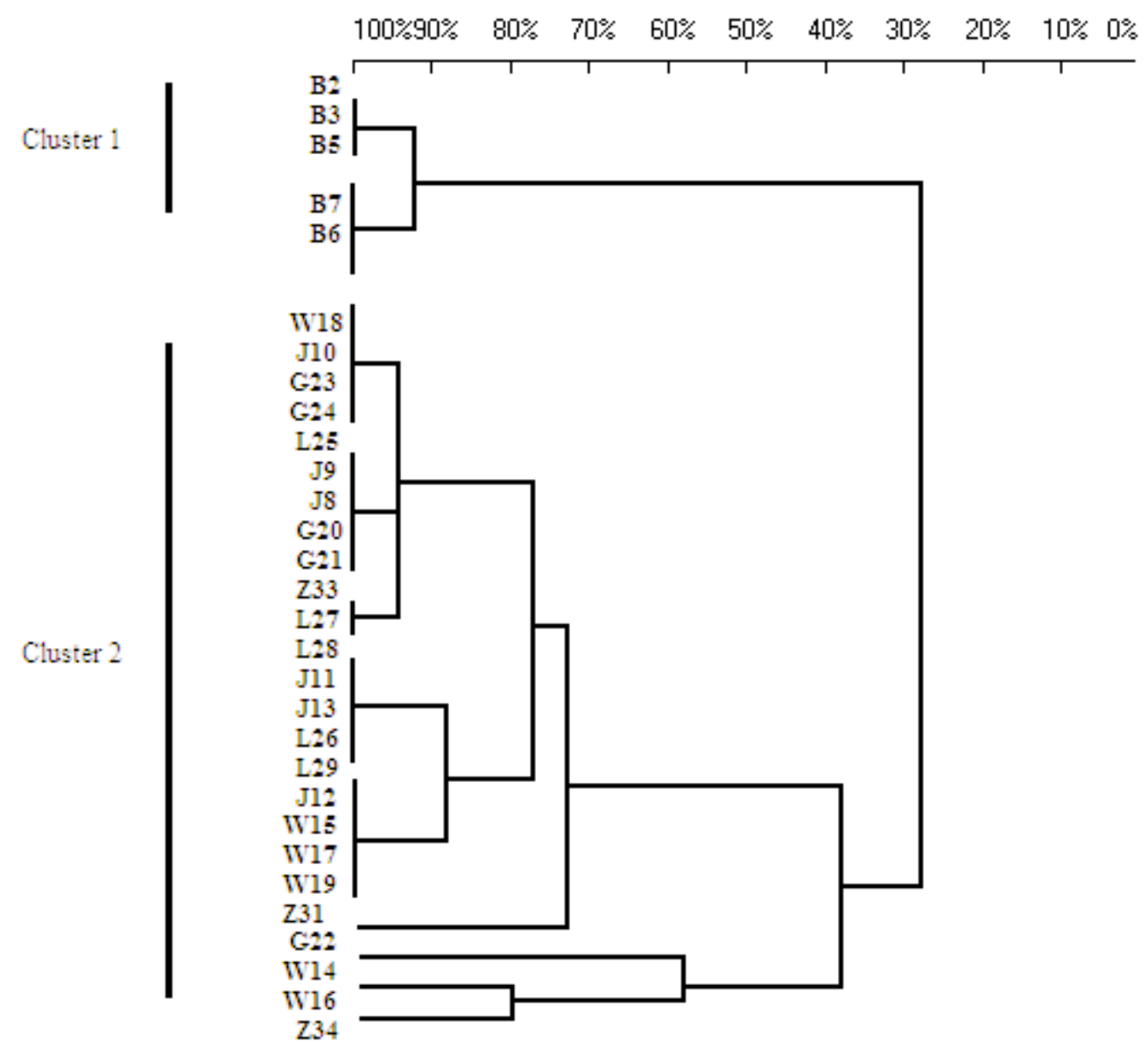

Fig. 3. The diagrams of the cluster analysis of RAPD pattern similarity matrix of the studied T. tenuicornis populations from Bolesław, Wełecz, Jasło, Grabowiec, Łuczyce, and Zurawica. The UPGMA method was used for analysis.

Elemental concentrations in cells

The results of X-ray microanalysis showed significant differences in all measured elements in leg muscle fibres of insects collected in Bolesław when compared with samples from unpolluted sites. The concentrations of $\mathrm{Na}, \mathrm{Cl}$ and $\mathrm{S}$ were significantly reduced by $79 \%, 30 \%$ and $6 \%$, respectively, in muscle cells of insects collected from Bolesław compared to those originating from Welecz. In contrast, the concentrations of K, P and $\mathrm{Mg}$ in muscle fibres were significantly higher, by $172 \%, 52 \%$ and $46 \%$, respectively, in the insects from Bolesław (Fig. 4A).

Cells in the brain of insects collected from contaminated and uncontaminated sites showed similar concentrations of all measured elements except $\mathrm{S}$ and $\mathrm{Cl}$, which had lower concentrations by $25 \%$ and $19 \%$, respectively, in insects originating from Bolesław as compared to samples from the unpolluted Wełecz site (Fig. 4B). These differences were statistically significant.

\section{Discussion}

In this study, natural populations of the geophile orthopteran species $T$. tenuicornis from polluted and unpolluted sites were examined at the population level in terms of diagnostic analysis of RAPD-PCR bands, as well as at the cellular level by examination of the concentration of physiologically important elements in excitable cells such as muscle fibers and brain cells. In these cells any changes in $\mathrm{Na}, \mathrm{K}, \mathrm{Cl}$ and $\mathrm{Mg}$ ion concentrations affect the resting potential of cell membranes and cell excitation. In turn, changes in concentration of $\mathrm{S}$ and $\mathrm{P}$ affect protein synthesis, such as metallothioneins important for metal binding, and cell metabolism.

The present data, gives evidence that support the RAPD analysis in determinig variability within a population. In a previous study T. tenuicornis was identified as a species typical for Paleoarctic xerotherms (WARCHAŁOWSKA-ŚLIWA et al. 2005), including habitats polluted with heavy metals, 

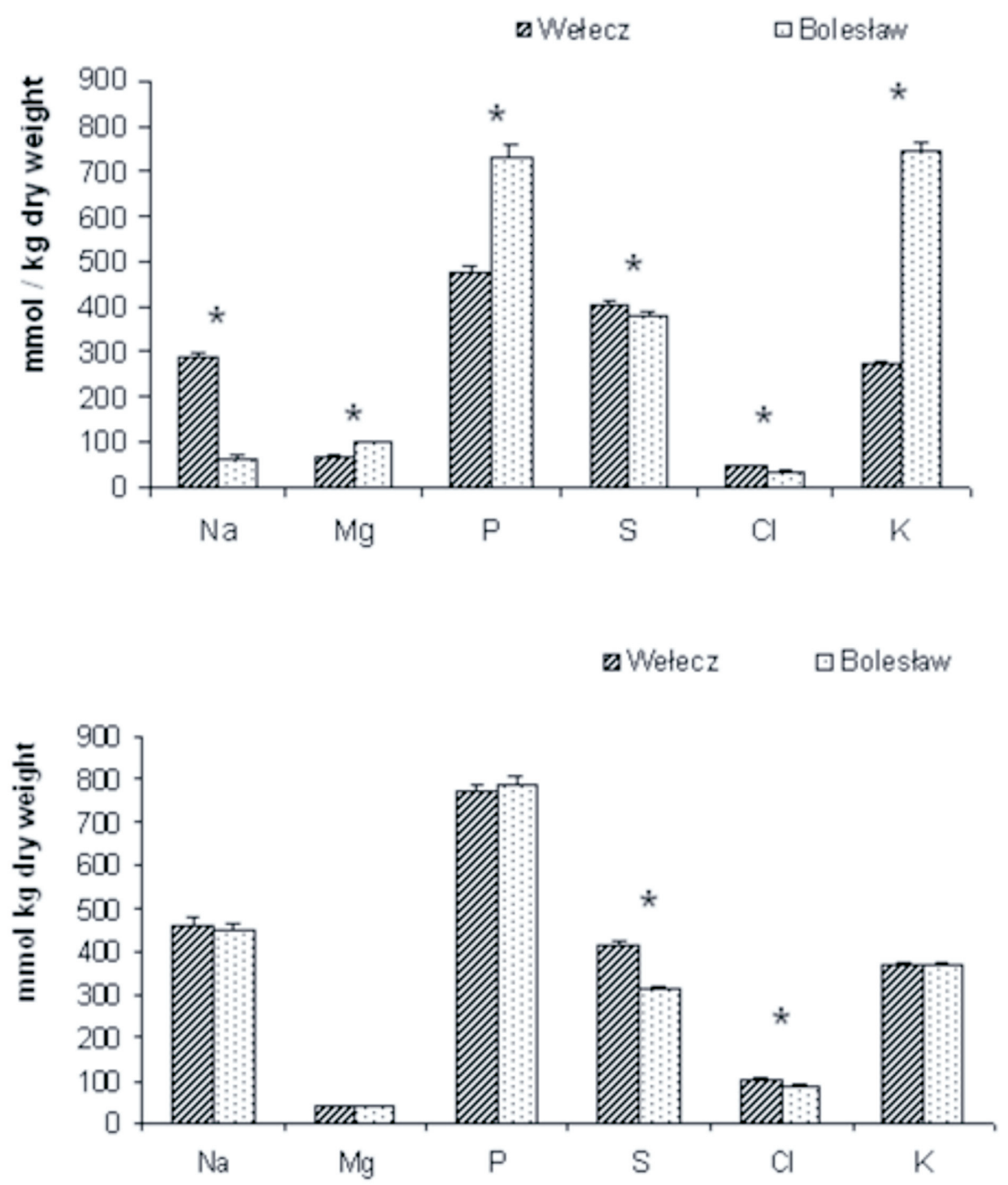

Fig. 4. The elemental composition of the muscle fibres (A) and nerve cells of the brain (B) of the insects collected from different sites, contaminated (Bolesław) and uncontaminated (Wełecz), as mean \pm SE. Asterisks indicate significant differences between groups at $\mathrm{P}<0.05$.

especially with $\mathrm{Zn}, \mathrm{Pb}, \mathrm{Fe}$ and $\mathrm{Cd}$, as in Bolesław (SZAREK-ŁUKASZEWSKA \& NIKLIŃSKA 2002). Thus, this species is a good model of investigation of the impact of heavy metals on natural populations and probably can be used as a bioindicator of heavy metal pollution in ecosystems (WARCHAŁOWSKA-ŚLIWA \& MARYAŃSKA-NADACHOWSKA 1991). We have already found that this species accumulates heavy metals and shows chromosomal aberration, however, the whole body concentration of heat shock protein Hsp70, known as a biomarker of heavy metal intoxication, was lower in insects living in contaminated as compared to clean habitats (WARCHAŁOWSKA-ŚLIWA et al. 2005). The decrease in Hsp70 concentration in tis- sues exposed to heavy metals may be the result of adaptation to this environment and/or the occurrence of other mechanisms of resistance to heavy metal toxicity, rather than the synthesis of stress proteins such as Hsp70, in this species.

In the present study, we examined two additional parameters in this species from polluted and unpolluted areas by assessing the genetic diversity of its populations and concentrations of important elements for cell metabolism in nerve and muscle cells to evaluate the physiological condition of insects from polluted sites.

In the first step we analysed the level of genetic diversity, which represents a new approach in ecotoxicology, by using seven primers. After genera- 
tion of clear, reproducible bands, their patterns were analyzed in order to characterize DNA polymorphism in six T. tenuicornis populations. The results show that band pattern are different in each population. Individuals from the contaminated Bolesław site were less polymorphic than specimens from uncontaminated sites in Wełecz, Jasło, Grabowiec, Łuczyce and Żurawica. There were found two genetic clusters among 30 individuals from six populations of $T$. tenuicornis by using RAPD method. First cluster concluded individuals from polluted areas from Bolesław and the second one contained specimens of five populations from unpolluted areas. NEI and LI'S (1979) similarity coefficient indicated that the within population similarity was the highest in samples from Bolesław and lower in Wełecz, Jasło, Grabowiec, Łuczyce and Żurawica. However, interpopulation comparisons showed that similarity coefficients between the populations from Bolesław and Jasło, as well as between Bolesław and Grabowiec or Bolesław and Łuczyce were higher than that of the populations from Wełecz and Grabowiec or Wełecz-Łuczyce. In general, these results suggest that metal pollution in Bolesław affects the genetic variability in this population. Molecular data presented differences at the DNA level between T. tenuicornis from polluted and unpolluted ares.

The population-genetic and evolutionary effects of contaminant exposure have been studied by other authors (e.g. BELFIORE \& ANDERSON 1988; BICKHAM et al. 2000; CRONIN \& BICKHAM 1998; ROSS et al. 2002; MULLER et al. 2007), and the RAPD-PCR technique has been applied in both plants and animals. This analysis has also wide applications in the study of genetic diversity between and among populations (e.g. APOSTOL et al. 1996; BLOK et al. 1997; CENIS 1993, TABERNER et al. 1997; GELETA et al. 2007), including ecotoxicological studies (NADIG et al. 1998; KRANE et al. 1999; BICKHAM et al. 2000; Ross et al. 2002).

It has been reported, however, that populations exposed to heavy metal pollution may either increase or decrease their genetic variation. For example, a reduction of genetic diversity has been observed in prawns and isopods exposed to a mixture of heavy metals including zinc, lead, cadmium, copper and manganese present in the marine environment surrounding a lead smelter (Ross et al. 2002). A decrease of polymorphism may occur as a result of selection for toxicant resistance but also depends on the species and in addition may be affected by other factors. In turn, new mutations may increase genetic variability and it is known that heavy metals have mutagenic effects on DNA and may indirectly decrease growth and reproduction and increase mortality in populations (THEODORAKIS \& SHUGART 1998). Changes in genetic variability may also be a consequence of adaptation to a contaminated environment (BICKHAM \& SMOLEN 1994), genetic drift, gene flow and/or selection in microevolutionary process which determine the pattern of genetic structure.

The observed genotypic differences between populations of the same species may be important in determining the physiological or ecological significance of altered gene frequencies in populations from polluted and unpolluted sites. Using the RAPD method for the evaluation of DNA polymorphism, it is possible to detect population genetic responses to chemical exposure. Several studies on aquatic organisms have shown higher genetic variability in populations originating from an environment with a low contamination level in comparison with populations living in a highly contaminated environment (RONG \& YIN 2004; MAES et al. 2005).

Toxic compounds affect organisms, but their survival depends not only on the presence or absence of environmental toxicants but also on population demographic properties (BICKHAM et al. 2000). Beside toxicants, genetic variability may also be altered by natural factors such as temperature and migration. Gene flow is increased as a result of migration of individuals between populations as well as hybridization and nucleotide substitution (BICKHAM et al. 2000).

The results showed that the RAPD-PCR technique is a useful method in ecotoxicological studies for the preliminary detection of phenetic/genetic variability within and between populations of $T$. tenuicornis. This study is the first report on the use of a DNA marker for the analysis of populations of T. tenuicornis from polluted and unpolluted areas.

The reduced genetic diversity of $T$. tenuicornis populations exposed to heavy metals seems to be a result of selective pressure, bottlenecks, and/or genetic drift on this species leading to the development of tolerance and resistance to these substances in the environment. However, future studies using more populations exposed and unexposed to high levels of heavy metals, using amplified fragment length polymorphism (AFLP) markers and microsatellite markers are needed to confirm the mechanisms of decreasing polymorphism in populations living under pressure of environmental pollutants.

Significant differences in element composition were detected between $T$. tenuicornis individuals collected from polluted and unpolluted ecosystems. The orthopterans collected in polluted sites near Bolesław accumulate 1.5, 4.03, 4.32 and 41.73 times more $\mathrm{Cu}, \mathrm{Zn}, \mathrm{Pb}$ and $\mathrm{Cd}$, respectively, than insects from unpolluted sites (WARCHAŁOWSKA-ŚLIWA et al. 2005). This affects the concentrations of vital elements in their cells, ex- 
amined in the present study, especially in cells which are not protected by specialized barriers such as muscle fibers. We found that concentrations of $\mathrm{Na}, \mathrm{Mg}, \mathrm{P}, \mathrm{S}, \mathrm{Cl}$ and $\mathrm{K}$ were significantly altered in muscle cells. The highest increase and decrease in concentration was in the case of $\mathrm{K}$ (by $172 \%$ ) and $\mathrm{Na}$ (by $79 \%$ ), which must affect the plasma membrane potential and excitability of muscle fibers. In contrast, cells in the brain, protected by the haemolymph/brain barrier, did not show significant changes in concentrations of the elements studied, except for $\mathrm{S}$ and $\mathrm{Cl}$. The increase of concentrations of $\mathrm{K}, \mathrm{Mg}$ and decrease of $\mathrm{Na}$ and $\mathrm{Cl}$ in muscle fibers of $T$. tenuicornis which has colonized zinc-lead mine spoils, suggests an influence of heavy metals on ion pumps and channels involved in regulation of ion concentrations in cytoplasm and in extracellular space. The concentration of $\mathrm{Na}^{+}$and $\mathrm{K}^{+}$ions inside cells is regulated by $\mathrm{Na}^{+} / \mathrm{K}^{+}$-ATPase and it is known that its structure and function is affected by heavy metals which catalyze cleavage of the $\mathrm{Na}^{+} / \mathrm{K}^{+}$-ATPase subunits (GOLDSHLEGER \& KARLISH 1997). In turn the increase of $\mathrm{P}$ and decrease of $\mathrm{S}$ concentrations indicate a possible increase of ATP production and decrease of protein synthesis, respectively.

Effects of heavy metals such as $\mathrm{Zn}, \mathrm{Cu}, \mathrm{Pb}$ and $\mathrm{Cd}$ on concentrations of $\mathrm{Na}, \mathrm{Mg}, \mathrm{P}, \mathrm{S}, \mathrm{Cl}$ and $\mathrm{K}$ in cells have also been studied in another insect species, the housefly, under laboratory conditions (TYLKO et al. 2005). In this study a similar increase of $\mathrm{K}$ and $\mathrm{P}$ and decrease of $\mathrm{Na}, \mathrm{P}$ and $\mathrm{S}$ concentrations in muscle cells of imagines was found after treating larvae with Cd with low $(3 \mu \mathrm{g} / \mathrm{g})$ or high $(50 \mu \mathrm{g} / \mathrm{g})$ concentrations in the rearing medium (TYLKO et al. 2005). Since the effects of other heavy metals including $\mathrm{Cu}, \mathrm{Zn}$ and $\mathrm{Pb}$ on the same elements were different, the changes in the elemental concentrations detected in the present study may result from the toxicity of cadmium.

In the present studies, we were able to show that T. tenuicornis living in the polluted environment in Bolesław has established a stable, genetically uniform population, however, heavy metal accumulated by these insects affects their genetic material and physiological processes but the toxic effects of heavy metals do not significantly increase their mortality, probably due to the tolerance developed by T. tenuicornis.

\section{Acknowledgments}

The work was funded by the Institute of Systematics and Evolution of Animals Polish Academy of Sciences.

\section{References}

Apostol B. L., Black W. C., Reiter P., Miller B. R. 1996. Population genetics with RAPD-PCR markers: the breeding structure of Aedes aegypti in Puerto Rico. Heredity 76: 325-334.

Atienzar F. A., Conradi M., Evenden A. J., Jha A. N., DEPLEDGE M. H. 1999. Qualitative assessment of genotoxicity using random amplified polymorphic DNA: comparison of genomic template stability with key fitness parameters in Daphnia magna exposed to benzo[a]pyrene. Environ. Toxicol. Chem. 18: 2275-2282.

AtienZar F. A., CORDi B., DONKIN M. E., EVEnden A. J., JHA A. N., DePledGE M. H. 2000. Comparison of ultraviolet-induced genotoxicity detected by random amplified polymorphic DNA with chlorophyll fluorescence and growth in a marine macroalgae, Palmaria palmate. Aquat. Toxicol. 50: 1-12.

Atienzar F. A., Cheung V. V., Jha A. N., DePledge M. H. 2001. Fitness parameters and DANN effects are sensitive indicators of copper induced toxicity in Daphnia magna. Toxicol. Sci. 59: 241-250.

Atienzar F. A., Venier P., Jha A. N., Depledge M. H. 2002a. Evaluation of the random amplified polymorphic DNA (RAPD) assay for the detection of DNA damage and mutations. Mutat. Res. 521: 151-163.

Atienzar F. A., Evenden A. J., JHA A. N., DePledge M. H. $2002 \mathrm{~b}$. Use of the random amplified polymorphic DNA (RAPD) for the detection of DNA damage and mutations: possible implication of confounding factors. Biomarkers 7: 94-101.

BARSYTE D., LOVEJOY D. A., LiTHGOW G. J. 2001. Longevity and heavy metal resistance in def-2 and age-1 long lived mutants of Caenorhabditis elegans. FASEB J. 15: 627-634.

BELFIORE N. M., ANDERSON S. L. 1988. Genetic patterns as a tool for monitoring and assessment of environmental impacts: the example of genetic ecotoxicology. Environ. Monit. Assess. 51: 465-479.

Bickham J. W., Sandhu S., HeBert P. D. N., Chikhi L., ATHWAL R. 2000. Effects of chemical contaminants on genetic diversity in natural populations: implications for biomonitoring and ecotoxicology. Mutation Res. 463: 33-51.

BickHAm J.W., SMOLEN M. J. 1994. Somatic and heritable effects of environmental genotoxins and the emergence of evolutionary toxicology. Envir. Health. Persp. 102: 25-28.

Black W. C., Duteau N. M., Puterka G. J., NeChols J. R., PETTORINI J. M. 1992. Use of the random amplified polymorphic DNA polymerase chain reaction (RAPD-PCR) to detect DNA polymorphisms in aphids. Bull. Ent. Res. 82: 151-159.

Blok V. C., Phillips M. S., Harrower B. E. 1997. Comparison of British populations of potato cyst nematodes with populations from continental Europe and South America using RAPDs. Genome 40: 286.

Bonacker D., Stoiber T., Bohm K. J., Prots I., WANG M., Unger E., Their R., BOLt H. M., DEgen G. H. 2005. Genotoxicity of inorganic lead salts and disturbance of microtubule function. Environ. Mol. Mutagen. 45: 346-353.

Borowska J., Sulima B., NikilińSKa M, PyZA E. 2004. Heavy metal accumulation and its effects on development, survival and immuno-competent cells of the housefly Musca domestica from closed laboratory populations as model organism. Fresenisus Environ. Bull. 13: 1402-1409.

Chiang H. C., Lo J. C., YeH K. C. 2006. Genes associated with heavy metal tolerance and accumulation in $\mathrm{Zn} / \mathrm{Cd}$ hyperaccumulator Arabidopsis halleri: a genomic survey with cDNA microarray. Environ. Sci. Technol. 40: 6792-6798.

CENIS J. L. 1993. Identification of four major Meloidogyne spp. Byrandom amplified polymorphic DNA (RAPD-PCR). Phytopathology 83: 77-80.

CRONIN M. A., BICKHAM J. W. 1998. A population genetic analysis of the potential for a crude oil spill to induce herita- 
ble mutations and impact natural populations. Ecotoxicology 7: 259-278.

Fraga J., RodrigueZ J., Fuentes O., FernandeZ-CALieNESI A., CASTEX M. 2005. Optimization of Random Amplified Polymorphic DNA Techniques for use in genetic studies of Cuban triatominae. Rev. Inst. Med. Trop. S. Paulo 47: 295-300.

FlorEA A.-M., BÜSSELBERG D. 2006. Occurrence, use and potential toxic effects of metals and metal compounds. BioMetals 19: 419-427.

Geleta M., BR Yngelsson T., BeKele E., Dagne K. 2007. AFLP and RAPD analyses of genetic diversity of wild and /or weedy Guizotia (Asteraceae) from Ethiopia. Hereditas 144: $53-62$.

GOLDSHLEGER R., KARLiSh S. J. D. 1997. Fe-catalyzed cleavage of the subunit of $\mathrm{Na} / \mathrm{K}-\mathrm{ATPase}$ : evidence for conformation-sensitive interactions between cytoplasmic domains. Proc. Natl. Acad. Sci. USA 19: 9596-9601.

Goldstein J. I., YAKOwITZ H. 1975. Practical Scanning Electron Microscopy. New York Plenum Press.

GRAUR D., LI W.-H. 2000. Fundamentals of Molecular Evolution. Sinauer Associates Sunderland, MA.

Hoffman A. A., PARSONS P. A. 1997. Extreme environmental change and evolution. Cambridge University Press.

JiANG G., LU G. 2003. Analysis of the genetic variations and phylogenetic relationship among three species of grasshopper genus Hieroglyphus (Orthoptera: Acridoidea: Catantopidae) using RAPD Markers. Entomotaxonomia 25: 88-90.

JONES C., KORTENKAMP A. 2000. RAPD library fingerprinting of bacterial and human DNA: applications in mutation detection. Teratogen. Carcinogen. Mutagen. 20: 49-63.

LI K., ZHENG Z. 2003. RAPD study of the genus Teleogryllus (Orthoptera: Grylloidea: Gryllidae) from China. Entomotaxonomia 25: 9-13.

KiM K. S., SAPPINGTON T. W. 2004. Genetic structuring of boll weevil populations in the US based on RAPD markers. Insect Mol. Biol. 13: 293-303.

Koller B., LeChMANN A., MCDERMOtT J. M., Gessler C. 1993. Identification of apple cultivars using RAPD markers. Theor. Appl. Genet. 85: 901-904.

Krane D. E., Sternberg D. C., Burton G. A. 1999. Randomly amplified polymorphic DANN profile-based measures of genetic diversity in crayfish correlated with environmental impacts. Environ. Toxicology and Chemistry 18: $504-508$.

LARK K. G., EVANS J., BASHA F., BOgDEN R., COPELAND R., ELLISON R., HORNE D., LEE K., MCDONALD K. PERSON J., SCHUSTER W., WiLheLM P., YU Y. 1992. Molecular phylogeny as a genetic tool for soybean breeding. Soyb. Genet News 19: 174-181.

Maes G. E., RaEymaekers J.A. M., Pampoulie C., SeyNAEVE A., GOEMANS G., BELPAIRE C., VOLCKAERT F. A. M 2005. The catadromous European ell Anquilla anquilla (L) as a model for freshwater evolutionary ecotoxicology: relationship between heavy metal bioaccumulation, condition and genetic variability. Aquat. Toxicol. 73: 99-114.

Muller L. A. H., Vangronsveld J., COLPAERT J. V. 2007. Genetic structure of Suillus luteus populations in heavy metal polluted and nonpolluted habitats. Mol. Ecol. 16: $4728-4737$.

NADIG G. S., LEE K. L., ADAMS S. M. 1998. Evaluating alterations of genetic diversity in sunfish populations exposed to contaminants using RAPD assay. Aquat. Toxicol. 43: 163-178.

NEI M., LI W. H. 1979. Mathematical model for studying genetic variation in terms of restriction endonucleases. Proc. Natl. Acad. Sci. USA 76: 5269-5273.

NEI M. (1987) Molecular evolutionary genetics. Columbia University Press New York USA.
Page R. D. M., Holmes E. C. 1998. Molecular Evolution: A phylogenetic approach. Blackwell Science Ltd. Oxford.

RONG Z., YIN H. 2004. A method for genotoxicity detection using random amplified polymorphism DNA with Danio rerio. Ecotoxicol. Environ. Saf. 58: 96-103.

Ross K., COOPER N., BIDWEll J. R., ElDER J. 2002. Genetic diversity and metal tolerance of two marine species: a comparison between populations from contaminated and reference sites. Marine Pollut. Bull. 44: 671-679.

SESARINI C., REMIS M. I. 2008. Molecular and morphometric variation in chromosomally differentiated populations of the grasshopper Sinipta dalmani (Orthoptera: Acrididae). Genetica 133(3): 295-306.

Sharma V. L., Gill M. T. K., Sharma S., BADRAn A.-A., SOBTI R. 2003. RAPD-PCR in two species of Catopsilia (Pieridae, Lepidoptera). Caryologia 56: 223-226.

SNEATH P. H. A. 1957. The application of computer to taxonomy, J. General. Microbiology 17: 201-226.

SOKAL R. R., MicheNER C. D. 1958. A statistical method for evaluating systematic relationships. Univ. Kansas Sci. Bull. 38: $1409-1438$.

STATHAM P. J. 1977. Deconvolution and background subtraction by least squares fitting with prefiltering of spectra. Anal. Chem. 49: 2149-2154.

Stiles J. I., LeMme C., SONDUR S., MORShidi M. B., MANSHARDT R. 1993. Using Randomly amplified polymorphic DNA for evaluating genetic relationships among papaya cultivars. Theor. Appl. Genet. 85: 697-701.

SZAREK-ŁUKASZEWSKA G., NIKILIŃSKA M. 2002. Concentration of alkaline and heavy metals In Bisctella laevigata $\mathrm{L}$. and Plantago lanceolata L. growing on calamine spoils (S. Poland). Acta Biol. Cracov. Ser. Bot. 44: 29-38.

Taberner A., Dopazo J., Castanera P. 1997. Genetic characterization of populations of a de novo arisen sugar beet pest Aubeonymus mariaefranciscae (Coleoptera: Curculionidae) by RAPD analysis. J. Mol. Evol. 45: 24.

THEODORAKIS C. W., SHUGART L. R. 1998. Genetic ecotoxicology III: the relationship between DNA strand breaks and genotype in mosquito fish exposed to radiation. Ecotoxicology 7: 227-236.

TYlKo G., BANACH Z., KilarSKi W. 2004. Proza and calibration curves for quantitative X-ray microanalysis of biological samples. Microchimica Acta 144: 271-276.

TYLKO G., BANACH Z., BOROWSKA J., NiKLIŃSKA M., PYZA E. 2005. Elemental changes in the brain, muscle, and gut cells of the housefly, Musca domestica, exposed to heavy metals. Micr. Res. Tech. 66: 239-247.

WARCHAŁOWSKA-ŚLIWA E., MARYAŃSKA-NADACHOWSKA A. 1991. Chromosome aberrations in a natural population of Tetrix tenuicornis (Sahlb.) (Tetrigidae: Orthoptera). Folia Biol. (Kraków) 3: 5-15.

WARChaŁowSKA-Śliwa E., NikiliŃSKA M., GÖRLICH A., MichAILOVA P., PYZA, E. 2005. Heavy metal accumulation, heat shock protein expression and cytogenetic changes in Tetrix tenuicornis (L.) (Tetrigidae, Orthoptera) from polluted areas. Env. Poll. 133: 373-381.

WiLLIAMS J. G. K., KUBELIK A. R., LiVAK K. J., RAFALSKI J. A., TINGEY S. V. 1991. DNA polymorphisms amplified by arbitary primers are useful as genetic markers. Nucleic. Acids Res. 18: 6531-6535.

Wolf De H., Blust R., Backeluau T. 2004. The use of RAPD in ecotoxicology. Mut. Research 566: 249-262.

ZAFAR S., AQIL F., AHMAD I. 2006. Metal tolerance and biosorption potential of filamentous fungi isolated from metal contaminated agricultural soil. Bioresour. Technol. 98: 2557-2561.

Zhou X., Faktor, O., Applebaum S. W., Coll M. 2000. Population structure of the pestiferous moth Helicoverpa armigera in the eastern Mediterranean using RAPD analysis. Heredity 85: 251-256. 